\title{
Long-term patient-reported satisfaction with different inflatable penile prosthesis: Comparison between AMS 700CX and Coloplast Titan
}

\author{
Afonso Morgado $^{a, *}$, Ana Sofía Cavadas ${ }^{b}$, Luis Pacheco Figueiredo ${ }^{a, c}$, Nuno Tomada ${ }^{a, d}$ \\ a Serviço de Urologia, Centro Hospitalar São João, Porto, Portugal \\ b Faculdade de Medicina da Universidade do Porto, Porto, Portugal \\ c Escola das Ciências da Saúde, Universidade do Minho, Braga, Portugal \\ d Departamento de Urologia, Faculdade de Medicina da Universidade do Porto, Porto, Portugal
}

Received 15 April 2017; accepted 24 July 2017

\author{
PALABRAS CLAVE \\ Inflable; \\ Pene; \\ Prótesis; \\ Satisfacción; \\ AMS; \\ $700 C X^{T M}$; \\ Coloplast; \\ $\operatorname{Titan}^{\circledR}$
}

\begin{abstract}
Introduction: Erectile dysfunction (ED) is one of the most prevalent male sexual disorders worldwide. When conservative treatment is unsuccessful, contraindicated or causes unacceptable side effects penile prosthesis implantation is a definitive option for the management of ED. Although considered a third-line therapy, it achieves the highest satisfaction rates as compared with non-surgical treatment. Three-piece inflatable penile prothesis (IPP) represents the most sophisticated implantable device, AMS $700 \mathrm{CX}^{\mathrm{TM}}$ and Coloplast Titan ${ }^{\circledast}$ being the two most commonly used. Although there are several studies evaluating patient satisfaction with either model, there is little published data comparing both models.

Methods: We have compared overall patient satisfaction in 55 patients submitted to either $700 \mathrm{CX}^{\mathrm{TM}}$ or $\operatorname{Titan}^{\circledast}$ implantation. The Erectile Dysfunction Inventory of Treatment Satisfaction (EDITS) questionnaire was used to access patient satisfaction.

Results: Patient mean age and follow-up time were 59.1 years and 57.9 months respectively. There was no difference in EDITS score between $700 \mathrm{CX}^{\mathrm{TM}}$ and $\operatorname{Titan}^{\oplus}$ IPP $(77.2 \pm 12.1$ versus $77.5 \pm 16.6$ respectively, $p=0.956$ ).

Conclusion: Overall patient satisfaction as assessed by EDITS questionnaire was not different between $700 \mathrm{CX}^{\mathrm{TM}}$ and $\operatorname{Titan}^{\oplus}$.

(๖) 2017 Asociación Española de Andrología, Medicina Sexual y Reproductiva. Published by Elsevier España, S.L.U. All rights reserved.
\end{abstract}

\footnotetext{
* Corresponding author.

E-mail address: luisafonsomorgado@gmail.com (A. Morgado).
}

http://dx.doi.org/10.1016/j.androl.2017.07.003

1698-031X/@ 2017 Asociación Española de Andrología, Medicina Sexual y Reproductiva. Published by Elsevier España, S.L.U. All rights reserved.

\footnotetext{
Please cite this article in press as: Morgado A, et al. Long-term patient-reported satisfaction with different inflatable penile prosthesis: Comparison between AMS 700CX and Coloplast Titan. Rev Int Androl. 2017. http://dx.doi.org/10.1016/j.androl.2017.07.003
} 


\author{
PALABRAS CLAVE \\ Inflable; \\ Pene; \\ Prótesis; \\ Satisfacción; \\ AMS; \\ $700 C X^{\top M}$; \\ Coloplast; \\ Titan $^{\oplus}$
}

\section{Satisfacción a largo plazo reportada por el paciente con diferentes prótesis de pene inflables: comparación entre AMS $700 \mathrm{CX}$ y Coloplast Titan}

\begin{abstract}
Resumen
Introducción: La disfunción eréctil (DE) constituye uno de los trastornos sexuales masculinos con mayor prevalencia a nivel mundial. Cuando el tratamiento conservador es infructuoso, está contraindicado, o causa efectos colaterales inaceptables, la implantación de prótesis de pene es una opción definitiva para el tratamiento de la DE. Aunque es considerada una terapia de tercera línea, alcanza unas tasas de satisfacción superiores en comparación con el tratamiento no quirúrgico. La prótesis de pene inflable de 3 piezas (IPP) constituye el dispositivo implantable más sofisticado, siendo AMS $700 \mathrm{CX}^{\mathrm{TM}}$ y Coloplast Titan ${ }^{\oplus}$ los 2 dispositivos más comúnmente utilizados. Aunque existen diversos estudios que evalúan la satisfacción del paciente con cada uno de los modelos, existen pocos datos publicados que comparen ambos.

Métodos: Comparamos la satisfacción general del paciente en 55 individuos a los que se realizó implantación de $700 \mathrm{CX}^{\mathrm{TM}}$ o Titan ${ }^{\oplus}$. Se utilizó el cuestionario Erectile Dysfunction Inventory of Treatment Satisfaction (EDITS) para valorar la satisfacción del paciente.

Resultados: La edad media de los pacientes y el tiempo de seguimiento fueron de 59,1 años y 57,9 meses, respectivamente. No se encontró diferencia alguna en cuanto a puntuación EDITS entre los IPP $700 C X^{T M}$ y $\operatorname{Titan}^{\oplus}(77,2 \pm 12,1$ frente a $77,5 \pm 16,6$, respectivamente; $p=0,956)$. Conclusiones: La satisfacción general del paciente, evaluada mediante el cuestionario EDITS, no arrojó diferencias entre $700 \mathrm{CX}^{\mathrm{TM}}$ y $\operatorname{Titan}^{\oplus}$.

(c) 2017 Asociación Española de Andrología, Medicina Sexual y Reproductiva. Publicado por Elsevier España, S.L.U. Todos los derechos reservados.
\end{abstract}

\section{Introduction}

Erectile dysfunction (ED) is defined as the consistent or recurrent inability of man to achieve and/or maintain an erection sufficient to permit satisfactory sexual performance. ${ }^{1}$ ED affects physical and psychosocial health and may substantially decrease the quality of life of sufferers and their partners. ${ }^{2}$ It is one of the most common male sexual disorders worldwide. ${ }^{3} \mathrm{~A}$ large community-based study that included adult men, aged 20-75 years, from eight different countries has reported an overall ED prevalence rate of $16 \%$. ED's prevalence increases with aging and is estimated to be at its highest in men aged $70-75$ years $(37 \%) .{ }^{4}$

Only few causes of ED have the potential to be cured by a cause-specific treatment. Most men with ED are treated with methods to achieve erection, regardless of its cause. At present, phosphodiesterase type 5 inhibitors (PDE5-I) are the treatment of choice for the majority of patients, regardless of the underlying ED etiology. ${ }^{5,6}$ The introduction of PDE5-I in 1998 has, indeed, revolutionized the management of ED, because of their efficacy, acceptance and safety. However, between $30 \%$ and $40 \%$ of ED patients do not respond to PDE5-I. ${ }^{5}$ Patients who do not respond to oral drug therapy and those who cannot tolerate or use PDE5-I because of specific contraindications may be given the option to be treated with either intracavernosal or intraurethral medical therapy, or with a vacuum constrictor device, ${ }^{5,6}$ which are effective for most causes of ED. However, they tend to have high dropout rates. ${ }^{7,8}$ In cases where conservative treatment is unsuccessful, contraindicated or causes unacceptable side effects, penile prosthesis implantation is a definitive option for the management of ED. Although considered a thirdline therapy, ${ }^{5,6}$ when properly selected, penile prosthesis implantation achieves the highest satisfaction rates, as compared with non-surgical treatments. ${ }^{9,10}$

Currently available penile prostheses can broadly be divided into semi-rigid and inflatable devices. Inflatable implants include two and three piece prosthesis. ${ }^{11,12} \mathrm{Hav}$ ing evolved from malleable and two-piece inflatable penile implants, the three-piece inflatable penile prothesis (IPP) represent the most sophisticated implantable device with the highest patient-reported satisfaction rates. ${ }^{13}$ Although there are several brands and models of inflatable threepiece IPP the two most commonly used models are $700 X^{\text {TM }}$ (AMS; American Medical Systems Inc., Minneapolis, MN, USA) and Titan ${ }^{\oplus}$ (Coloplast Corp., Minneapolis, MN, USA). Several studies have reported on the outcomes and patient satisfaction with individual model penile prosthesis implantation. ${ }^{14-21}$ Patient satisfaction with ED's treatment is often accessed through either a visual analog scale or the Erectile Dysfunction Inventory of Treatment Satisfaction (EDITS) questionnaire.

The patient version of the EDITS questionnaire is a validated eleven question tool to access overall patient satisfaction with ED treatment. ${ }^{22}$ As previously stated it has been thoroughly used in the past to access patient satisfaction with individual penile prothesis models. Frequently modified version are applied where original questions are replaced by treatment-specific questions. ${ }^{21,23}$ When inflatable penile prothesis are concerned EDITS score has been show to rise steady until at least one year after surgery while early assessment (three and six months) might show less satisfactory results. ${ }^{24}$ 
Although there are several studies evaluating patient, partner and surgeon satisfaction as well as specific components and technological advances of a single model, there is little published data comparing IPP models. ${ }^{19,25}$ Currently, IPP model selection is based solely on pricing and surgeon preference disregarding patient satisfaction or preference. The main aim of this study is to compare overall patient satisfaction after implantation of either AMS $700 \mathrm{CX}^{\mathrm{TM}}$ or Coloplast Titan ${ }^{\circledR}$ IPP for the treatment of ED.

\section{Material and methods}

After obtaining institutional ethics review board approval, a retrospective study was conducted between January 2006 and December 2014. After review of the medical records a total of 55 men submitted to either AMS 700 CX ${ }^{\mathrm{TM}}$ or Coloplast $\operatorname{Titan}^{\circledR}$ IPP implantation who could potentially meet the inclusion and exclusion criteria were identified (Table 1). Data regarding patients' demographics and preoperative comorbid conditions, model of prosthesis used, peri and postoperative complications were collected. Patients were submitted to prothesis implantation through a standardized penoscrotal implant technique by the same surgical team and were taught how to operate the device 4-6 weeks after surgery as per standardized institution protocol. Thereafter patients were followed up at 3 months, 6 months and once a year thereafter.

Current mechanical status of the prosthesis and patient satisfaction with the device were assessed by either telephone or face-to-face interview, according to each patient's preference after informed consent was obtained. Patient preoperative erectile function was accessed through the validated translated version of the briefed International Index of Erectile Function (IIEF-5). Patient satisfaction was evaluated using a validated version of Erectile Dysfunction Inventory of Treatment Satisfaction (EDITS) questionnaire. Questions 5 and 6 of the original EDITS were not included as they were not appropriate for this treatment. Although IIEF-5 was also applied at followup results are not shown as question 2 to 4 was always 5 and both questions 1 and 5 are already part of the EDITS. Statistical analyses were performed using SPSS ${ }^{T M} 24.0$ (IBM SPSS Inc., Chicago, IL, USA). A $p$ value below 0.05 was considered significant. A Student's

Table 1 Inclusion and exclusion criteria. A non-functional penile prosthesis was defined as inability to fully inflate due to mechanical failure.

Inclusion criteria

Acceptance by the patient and informed consent

Older than 18 years old

Inflatable penile prothesis model either AMS 700CX ${ }^{\mathrm{TM}}$

or Coloplast Titan

\section{Exclusion criteria}

A non-functional penile prothesis at the time of the study The inflatable penile prothesis model should have been implanted at least 1 year before the study

Lack of stable partner

New onset comorbidity that could impair penile prothesis use
Table 2 Patient's characteristics.

\begin{tabular}{|c|c|c|c|}
\hline & $\begin{array}{l}\text { AMS } \\
700 C X^{T M}\end{array}$ & $\begin{array}{l}\text { Titan } \\
\text { Coloplast }^{\circledast}\end{array}$ & $p$ \\
\hline Number of patients & 27 & 12 & \\
\hline Age (years $\pm S D)$ & $57.78 \pm 8.51$ & $61.48 \pm 5.9$ & 0.131 \\
\hline Preoperative IIEF5 & $5.67 \pm 0.87$ & $5.67 \pm 0.88$ & 1.00 \\
\hline $\begin{array}{l}\text { Median follow up } \\
\text { (months } \pm S D \text { ) }\end{array}$ & $47.69 \pm 16.96$ & $682.83 \pm 19.32$ & 0.00 \\
\hline $\begin{array}{l}\text { Postoperative } \\
\text { complication (n) }\end{array}$ & & & 0.006 \\
\hline Mechanical failure & $4(33.3 \%)$ & $1(3.7 \%)$ & \\
\hline Etiology (n) & & & 0.674 \\
\hline Vasculogenic & $2(16.7 \%)$ & $2(7.4 \%)$ & \\
\hline Diabetes mellitus & $4(33.3 \%)$ & $8(29.6 \%)$ & \\
\hline Radical prostatectomy & $4(33.3 \%)$ & $12(44.4 \%)$ & \\
\hline Other pelvic surgery & $1(8.3 \%)$ & $4(14.8 \%)$ & \\
\hline Peyronie's disease & $1(8.3 \%)$ & $1(3.7 \%)$ & \\
\hline
\end{tabular}

Abbreviations: SD, standard deviation.

$t$-test was used to compare samples when a normal distribution was verified, otherwise a Mann-Whitney $U$ test was used. Chi-squared was used to access sampling distribution. Multiple regression was used to determine if the observed EDITS scores could be predicted by patients characteristics at the baseline, postoperative complications, time of follow-up or the type of prosthesis implanted.

\section{Results}

A total of 55 men that underwent penile prothesis implantation of either AMS $700 \mathrm{CX}^{\mathrm{TM}}$ or Coloplast Titan ${ }^{\circledR}$ between January 2006 and December 2014 could potentially meet the inclusion and exclusion criteria (Table 1). Thirty nine of patients accepted to answer the satisfaction questionnaire, 13 patients were lost to follow-up and unreachable while 2 patients were deceased resulting in a response rate of $70.9 \%$. No patient refused to consent and participate. A total of 27 and 12 patients were included in the $700 C X^{T M}$ and $\operatorname{Titan}^{\circledR}$ group respectively. At the time of surgery, the median age \pm standard deviation (SD) for the $700 \mathrm{CX}^{\mathrm{TM}}$ patients was $57.78 \pm 8.51$ years whereas it was $61.48 \pm 5.9$ years for the $\operatorname{Titan}^{\circledR}$ patients and median followup times was $47.69 \pm 16.96$ and $82.83 \pm 19.32$ months for former and latter respectively. The mean preoperative IIEF5 was $6.67 \pm 0.83$ versus $6.67 \pm 0.88$, for $700 C^{\mathrm{TM}}$ and $\operatorname{Titan}^{\circledR}$ patients, respectively. There was no statistically significant difference in age $(p=0.131)$, yet the Titan ${ }^{\circledR}$ follow-up was longer than the $700 C X^{\top M}(p=0.00)$. There were more postoperative complications requiring or not penile prosthesis revision surgery in the Coloplast $\operatorname{Titan}^{\circledR}, 33.3 \%$ versus $3.7 \%$ for $700 C X^{T M}(p=0.006)$. Additional variables were analyzed in each group such as age, body mass index, relevant medical history such as hypertension, diabetes mellitus, dislipidemia, prior pelvic surgery, prior radiotherapy. No statistically significant differences were found between groups for any of these variables, therefore the groups were assumed as homogenous regarding demographic characteristics (Table 2). 
Table 3 EDITS questionnaire individual questions and score.

\begin{tabular}{|c|c|c|c|}
\hline EDITS questions & AMS $700 C X^{T M} n(\%)$ & Titan Coloplast ${ }^{\oplus}(\%)$ & $p$ \\
\hline 1. Overall, how satisfied are you with this treatment? & & & 0.481 \\
\hline a. Very satisfied & $15(55.6)$ & $6(50.0)$ & \\
\hline b. Somewhat satisfied & $9(33.3)$ & $4(33.3)$ & \\
\hline c. Neither satisfied nor dissatisfied & $3(11.1)$ & $1(8.3)$ & \\
\hline d. Somewhat dissatisfied & $0(0)$ & $1(8.3)$ & \\
\hline e. Very dissatisfied & $0(0)$ & $0(0)$ & \\
\hline
\end{tabular}

2. During the past four weeks, to what degree has the treatment met your expectations?
a. Completely
b. Considerably
c. Half way
d. A little
e. Not at all
10 (37.0)
12 (44.4)
1 (3.7)
4 (14.8)
0 (0)
$19(70.4)$
8 (29.6)
0 (0)
0 (0)
0 (0)

3. How likely are you to continue using this treatment?
a. Very likely
b. Moderately likely
c. Neither likely nor unlikely
d. Moderately unlikely
e. Very unlikely

0.920

0.583

4. During the past four weeks, how easy was it for you to use this treatment?
a. Very easy
b. Moderately easy
c. Neither easy nor difficult
d. Moderately difficult
e. Very difficult

7. How confident has this treatment made you feel about your ability to engage in sexual activity?
a. Very confident
b. Somewhat confident
c. It has had no impact
d. Somewhat less confident
e. Very much less confident

8. Overall, how satisfied do you believe your partner is with the effects of this treatment?
a. Very satisfied
b. Somewhat satisfied
c. Neither satisfied nor dissatisfied
d. Somewhat dissatisfied
e. Very dissatisfied
$6(22.2)$
$16(59.3)$
$4(14.8)$
$1(3.7)$
0 (0)

5 (41.7)

4 (33.3)

1 (8.3)

2 (16.7)

0 (0)
$9(75.0)$
$2(16.7)$
0 (0)
0 (0)

9. How does your partner feel about your continuing to use this treatment?

$16(59.3)$
$3(11.1)$
$8(29.6)$
$0(0)$
$0(0)$

7 (25.9)

$14(51.9)$

$1(3.7)$

5 (18.5)

$0(0)$

)

you used this treatment over the past four weeks?
a. Very natural
b. Somewhat natural
c. Neither natural nor unnatural
d. Somewhat unnatural
e. Very unnatural

$$
\begin{aligned}
& 9(75.0) \\
& 1(8.3) \\
& 1(8.3) \\
& 1(8.3)
\end{aligned}
$$$$
0(0)
$$ 
Table 3 (Continued)

\begin{tabular}{|c|c|c|c|}
\hline EDITS questions & AMS $700 C X^{T M} n(\%)$ & Titan Coloplast ${ }^{\oplus}(\%)$ & $p$ \\
\hline $\begin{array}{l}\text { 11. Compared to before you had an erection problem how would you } \\
\text { rate the naturalness of your erection when you used this treatment } \\
\text { over the past four weeks in terms of hardness? }\end{array}$ & & & 0.245 \\
\hline a. A lot harder than before I had an erection problem & $6(22.2)$ & $3(25.0)$ & \\
\hline b. Somewhat harder than before I had an erection problem & $8(29.6)$ & $6(50.0)$ & \\
\hline c. The same hardness as before I had an erection problem & $6(22.2)$ & $2(16.7)$ & \\
\hline d. Somewhat less hard than before I had an erection problem & $7(25.9)$ & $1(8.3)$ & \\
\hline e. A lot less hard than before I had an erection problem & $0(0)$ & $0(0)$ & \\
\hline Mean EDITS score \pm SD & $77.24 \pm 12.14$ & $77.54 \pm 16.60$ & 0.956 \\
\hline
\end{tabular}

EDITS, Erectile Dysfunction Inventory of Treatment Satisfaction; SD, standard deviation.

The patients' overall responses to the EDITS questionnaire are presented in Table 3. Satisfaction, as assessed by EDITS score, was not different between $700 C X^{\top M}$ and Titan ${ }^{\circledR}$ IPP $(77.2 \pm 12.1$ versus $77.5 \pm 16.6$ respectively, $p=0.956)$. No differences were found regarding fulfillment of expectations, will to continue using or easiness of use between the two models. There were mostly positive answers in all individual questions. As shown by multiple regression, the age at the time of the surgery, cause of $E D$, preoperative IIEF-5, postoperative complication, follow-up time and type of prosthesis implanted did not significantly influence EDITS scores as presented in Table 2.

There were no statistically significant differences in all nine individual answers of EDITS questionnaire between the $700 C X^{T M}$ and $\operatorname{Titan}^{\circledR}$ IPP groups. The overall satisfaction rate \pm SD was high in both $700 C X^{T M}$ and Titan ${ }^{\circledR}$ groups, $77.24 \pm 12.14$ versus $77.54 \pm 16.60$ without a significant difference between them $(p=0.956)$. As shown by multiple regression, the age at the time of the surgery, cause of $E D$, follow-up time and type of prosthesis implanted did not significantly influence EDITS scores.

\section{Discussion}

To our current knowledge this retrospective comparison has the longest reported follow up time. It is also one of the fewest intended comparison of patient overall satisfaction with erectile dysfunction treatment with AMS $700 \mathrm{CX}^{\mathrm{TM}}$ and Coloplast $\operatorname{Titan}^{\circledR}$ IPP models.

The main upside of our study is the long follow up time observed as a mean of 47.69 and 82.83 months were noted for both $700 C X^{T M}$ and Titan $^{\circledR}$ respectively. Mulhall et al. accessed 96 patients sequentially at 3, 6 and 12 months after penile prothesis implantation using EDITS. As patient overall satisfaction was significantly the highest at 12 months they reported that satisfaction increases in year 1 after implant surgery with significant improvements in the second half of year $1 .^{24}$ The variability of patient satisfaction past the first postoperative year is yet to be evaluated. Even though our sample is relatively small, this long follow up period provides an unique look toward long term patient satisfaction with both $700 C X^{\mathrm{TM}}$ and $\operatorname{Titan}^{\circledR}$ implantable penile prothesis allowing a mature comparison and excluding potential bias from a the postoperative period and short follow up.
Contemporary tree-piece IPPs models are consistently associated with high rates of patient overall satisfaction. There are only three studies comparing AMS $700 \mathrm{CX}^{\mathrm{TM}}$ with Coloplast Titan ${ }^{\circledR}$ implants in terms of patient overall satisfaction. A recent study from Greece was conducted in 90 patients to assess the patients' erectile function and satisfaction after IPP implantation as well as the relationship between patient and partner satisfaction. ${ }^{25}$ Although it was not specifically designed to compare different types of prosthesis, the authors reported that patient satisfaction, as assessed by EDITS questionnaire, did not differ significantly between devices implanted. AMS 700CX ${ }^{T M}$ and Coloplast $\operatorname{Titan}^{\circledR}$ were included among the models implanted. Another recent study examined the clinical outcomes and patient satisfaction in 138 men with coexisting ED and Peyronie's disease treated with either Coloplast $\operatorname{Titan}^{\circledR}$ or AMS 700CX ${ }^{\top M}$ IPP. ${ }^{19}$ However, only a visual analog scale was used to access and compare treatment satisfaction and no differences were noted. More recently, Otero et al. conducted the largest retrospective study with 248 patients comparing satisfaction with either AMS $700 C^{T M}$ or Coloplast Titan ${ }^{\circledR}$ implantable penile prothesis for the treatment of erectile dysfunction. ${ }^{21}$ Concomitant Peyronie's disease or previous penile surgery were exclusion factors.

As expected there was a high satisfaction with penile prothesis implantation on both groups. Moreover, there appear to be no significant difference between AMS 700CX ${ }^{\mathrm{TM}}$ and $\operatorname{Titan}^{\circledR}$ groups regarding both patient's satisfaction, as assessed by EDITS' question 1, as well as overall satisfaction, as assessed through the final EDITS score. Moreover, EDITS questions answers were not influenced by baseline characteristics as shown by multiple regression analysis. As previously stated, Otero et al. also compared the aforementioned models in 248 patients using a modified non validated EDITS questionnaire and reported that there were more patients satisfied with $700 \mathrm{CX}^{\mathrm{TM}}$. They further stated that even though there was a difference in satisfaction, the majority of patients in both groups had positive outputs regarding question $1 .^{21}$ Indeed they noted a disparity in the proportion of "very satisfied" to "satisfied" answers ( $70 \%$ to $24 \%$ versus $44 \%$ to $44 \%$ in $700 C X$ and $\operatorname{Titan}^{\circledR}$ groups, respectively). ${ }^{21}$ We did not observe such a difference in question 1 neither there was a so significant disproportion between "very pleased" and pleased"' answers in $700 \mathrm{CX}^{\mathrm{TM}}$ (50\% "very pleased"' to $33.3 \%$ "pleased"). 
Our study design presents some limitations from its retrospective design as well as lack of randomization in penile prothesis model selection. An attrition bias is highly unlikely as stated by the high response rate $(70.9 \%)$ to questionnaire along with no refusal to participate. Patients that did not participate were either deceased or unreachable by neither phone or mail. A model selection bias is also highly unlikely as inflatable penile prothesis model selection was restricted by hospital adjudication policies. This lack of randomization or even surgeon model selection led to significant differences in patient follow up time, although long follow ups were observed in both groups. Furthermore there is no evidence that IPP model selection was based on individual patient characteristics which could jeopardize our comparison as patient demographics, ED's etiology and comorbidities were not different between groups. Thus samples were considered to be comparable.

In the future meta-analysis of retrospective comparisons like ours or even a prospective randomized trial might confirm or refute if there are in fact no differences between inflatable penile prothesis models when patient and partner overall satisfaction are regarded.

The two most used three piece implantable penile prothesis $700 C X^{\top M}$ and $\operatorname{Titan}^{\circledR}$ do not have significant overall patient satisfaction differences. Moreover there were also no differences noted in all individual questions of EDITS between the aforementioned models. Technically both penile prostheses are very similar in their design, only differing in their material constituents and small technical details like reservoir shape and pump mechanism. This differences do not seem to lead to meaningful differences in overall patient satisfaction with erectile dysfunction treatment with either three piece inflatable penile prothesis model.

\section{Ethical disclosures}

Protection of human and animal subjects. The authors declare that no experiments were performed on humans or animals for this study.

Confidentiality of data. The authors declare that they have followed the protocols of their work center on the publication of patient data.

Right to privacy and informed consent. The authors have obtained the written informed consent of the patients or subjects mentioned in the article. The corresponding author is in possession of this document.

\section{Conflict of interest}

The authors declare no conflict of interest.

\section{References}

1. Lizza EF, Rosen RC. Definition and classification of erectile dysfunction: report of the Nomenclature Committee of the International Society of Impotence Research. Int J Impot Res. 1999;11:141-3.
2. Feldman HA, Goldstein I, Hatzichristou DG, Krane RJ, McKinlay JB. Impotence and its medical and psychosocial correlates: results of the Massachusetts Male Aging Study. J Urol. 1994;151:54-61.

3. Laumann EO, Nicolosi A, Glasser DB, Paik A, Gingell C, Moreira $E$, et al. Sexual problems among women and men aged 40-80 $\mathrm{y}$ : prevalence and correlates identified in the Global Study of Sexual Attitudes and Behaviors. Int J Impot Res. 2005;17:39-57.

4. Rosen RC, Fisher WA, Eardley I, Niederberger C, Nadel A, Sand $M$, et al. The multinational Men's Attitudes to Life Events and Sexuality (MALES) study: I. Prevalence of erectile dysfunction and related health concerns in the general population. Curr Med Res Opin. 2004;20:607-17.

5. Porst H, Burnett A, Brock G, Ghanem H, Giuliano F, Glina S, et al. SOP conservative (medical and mechanical) treatment of erectile dysfunction. J Sex Med. 2013;10:130-71.

6. Hatzimouratidis K, Giuliano F, Moncada I, Muneer A, Salonia A, Verze P. EAU guidelines on erectile dysfunction, premature ejaculation, penile curvature and priapism. European Association of Urology Website; 2016 [Limited March 2016 Update]. Available from: http://uroweb.org/guideline/male-sexual-dysfunction/

7. Linet OI, Ogrinc FG, The Alprostadil Study Group. Efficacy and safety of intracavernosal alprostadil in men with erectile dysfunction. N Engl J Med. 1996;334:873-7.

8. Porst H, Buvat J, Meuleman E, Michal V, Wagner G. Intracavernous Alprostadil Alfadex - an effective and well tolerated treatment for erectile dysfunction. Results of a long-term European study. Int J Impot Res. 1998;10:225-31.

9. Rajpurkar A, Dhabuwala CB. Comparison of satisfaction rates and erectile function in patients treated with sildenafil, intracavernous prostaglandin E1 and penile implant surgery for erectile dysfunction in urology practice. J Urol. 2003;170:159-63.

10. Hatzimouratidis K, Hatzichristou DG. A comparative review of the options for treatment of erectile dysfunction: which treatment for which patient? Drugs. 2005;65:1621-50.

11. Sadeghi-Nejad H. Penile prosthesis surgery: a review of prosthetic devices and associated complications. J Sex Med. 2007;4:296-309.

12. Simmons M, Montague DK. Penile prosthesis implantation: past, present and future. Int J Impot Res. 2008;20:437-44.

13. Bernal RM, Henry GD. Contemporary patient satisfaction rates for three-piece inflatable penile prostheses. Adv Urol. 2012;2012:707321.

14. Goldstein I, Newman L, Baum N, Brooks M, Chaikin L, Goldberg $\mathrm{K}$, et al. Safety and efficacy outcome of mentor alpha-1 inflatable penile prosthesis implantation for impotence treatment. J Urol. 1997; 157:833-9.

15. Montorsi F, Rigatti P, Carmignani G, Corbu C, Campo B, Ordesi G, et al. AMS three-piece inflatable implants for erectile dysfunction: a long-term multi-institutional study in 200 consecutive patients. Eur Urol. 2000;37:50-5.

16. Minervini A, Ralph DJ, Pryor JP. Outcome of penile prosthesis implantation for treating erectile dysfunction: experience with 504 procedures. BJU Int. 2006;97:129-33.

17. Wilson SK, Delk JR, Salem EA, Cleves MA. Long-term survival of inflatable penile prostheses: single surgical group experience with 2,384 first-time implants spanning two decades. J Sex Med. 2007;4 Pt 1:1074-9.

18. Ohl DA, Brock G, Ralph D, Bogache W, Jones L, Munarriz R, et al. Prospective evaluation of patient satisfaction, and surgeon and patient trainer assessment of the Coloplast titan one touch release three-piece inflatable penile prosthesis. J Sex Med. 2012;9:2467-74.

19. Chung E, Van CT, Wilson I, Cartmill RA. Penile prosthesis implantation for the treatment for male erectile dysfunction: clinical outcomes and lessons learnt after 955 procedures. World J Urol. 2013;31:591-5. 
20. Ji YS, Ko YH, Song PH, Moon KH. Long-term survival and patient satisfaction with inflatable penile prosthesis for the treatment of erectile dysfunction. Korean J Urol. 2015;56:461-5.

21. Otero JR, Cruz CR, Gomez BG, Geli JS, Polo JM, Castane ER, et al. Comparison of the patient and partner satisfaction with 700CX and Titan penile prostheses. Asian J Androl. 2017;19:321-5.

22. Althof SE, Corty EW, Levine SB, Levine F, Burnett AL, McVary $\mathrm{K}$, et al. EDITS: development of questionnaires for evaluating satisfaction with treatments for erectile dysfunction. Urology. 1999;53:793-9.
23. Casabe AR, Sarotto N, Gutierrez C, Bechara AJ. Satisfaction assessment with malleable prosthetic implant of Spectra (AMS) and Genesis (Coloplast) models. Int J Impot Res. 2016.

24. Mulhall JP, Ahmed A, Branch J, Parker M. Serial assessment of efficacy and satisfaction profiles following penile prosthesis surgery. J Urol. 2003;169:1429-33.

25. Vakalopoulos I, Kampantais S, loannidis S, Laskaridis L, Dimopoulos P, Toutziaris C, et al. High patient satisfaction after inflatable penile prostheses implantation correlates with female partner satisfaction. J Sex Med. 2013;10:2774-81. 